\title{
Um efnahag og farsóttir
}

Á undanförnum mánuðum hefur farsóttin COVID-19 haft mikil áhrif á efnahag landsins. Viðbrögð við faraldrinum eru ákvörðuð af sóttvarnalækni og beinast að pví að milda faraldurinn en viðbrögðin hafa jafnframt umtalsverð hagfræðileg áhrif. Hagrænu áhrifin skipta máli vegna pess að pau koma fram í lífskjörum pjóðarinnar í nútíð og framtíð og einnig möguleikum á bættu heilbrigðiskerfi í framtíðinni.

Lykillinn að pví að hægja á farsótt er að takmarka samneyti fólks. Pannig hefur fólk neikvæð „ytri áhrif" hvert á annað í farsótt. En samneyti fólks er mikilvægt fyrir alla efnahagsstarfsemi. pjónusta felur yfirleitt í sér samneyti fólks en pjónustugreinarnar hafa orðið fyrir miklu höggi í farsóttinni. Tekist hefur að komast fyrir farsóttina hér á landi og hún er í rénun í mörgum öðrum löndum en samdráttur efnahagslífsins hér á landi vegna farsóttarinnar er nú sá mesti síðan árið 1920. Landsframleiðsla mun minnka um $8 \%$ á pessu ári og atvinnuleysi er komið í 17,8\% ef fólk á hlutabótum er tekið með. Í Bandaríkjunum eru 33 milljónir nú án atvinnu í mestu kreppu sem orðið hefur frá fjórða áratug síðustu aldar.

Við ákvarðanir um sóttvarnir togast á annars vegar viðleitni til pess að fækka smitum og hins vegar löngunin til pess að valda ekki óparflega miklum efnahagslegum skaða. ${ }^{1}$ I öðrum ríkjum, til dæmis Bandaríkjunum, hefur pessi togstreita valdið pví að byrjað er að slaka á sóttvörnum pótt ekki sjái fyrir endann á farsóttinni. Pá eru heilbrigðissjónarmið sett til hliðar vegna pess að hin efnahagslega fórn er talin vera of mikil.

Vegna góðs árangurs heilbrigðisyfirvalda hér á landi er staða Íslands allt önnur. Smit eru að mestu hætt að greinast og pjóðfélagið að færast í eðlilegt horf. Pannig er hægt að slaka á sóttvörnum og efla efnahag landsins án pess að stefna heilsu fólks í hættu. Petta er öfundsverð staða. Рað skiptir miklu máli fyrir efnahaginn að fólk geti mætt til vinnu, sótt sér ýmiss konar pjónustu, að skólastarf geti farið fram og sjómenn farið óhræddir til veiða. Pessi góði árangur skapar forsendur fyrir viðsnúningi í efnahagsmálum. Hagstjórn örvar pá innlenda eftirspurn með lágum vöxtum og aukningu ríkisútgjalda og
Íslendingar munu væntanlega ferðast innan lands sem aldrei fyrr nú í sumar. Hagkerfið mun smám saman ná sér á strik svo lengi sem nýr faraldur verður ekki á haustmánuðum.

Ýmsir kalla á að landið verði „opnað“ að nýju nú í sumar, að erlendir ferðamenn komi sem fyrst til pess að bæta efnahag ferðapjónustu og Íslendingar fái að fara til útlanda án pess að fara í sóttkví pegar heim er komið. Pótt gott sé að fá viðbótargjaldeyristekjur skapa slík ferðalög hættu á nýjum faraldri. Ferðalögin koma peim vel sem pjóna erlendum ferðamönnum og íslenskir ferðamenn munu njóta utanlandsferða sinna en pessir aðilar geta mögulega spillt fyrir öðrum, í versta falli orðið til pess að slæmur faraldur verði í haust, sem mundi lama hagkerfið að nýju.

Pað skiptir pá höfuðmáli hvort unnt sé að „opna“ landið en jafnframt að koma í veg fyrir að farsóttin berist til landsins. Pótt einhverjir ferðamenn komi í kjölfar slíkrar opnunar er ólíklegt að peir verði nægilega margir á næstunni til pess að skipta sköp-

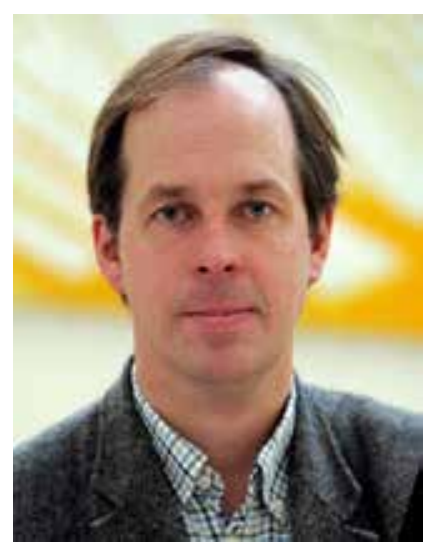

Gylfi Zoëga

Prófessor í hagfræði við Háskóla Íslands, doktor í hagfræði

gz@hi.is um fyrir próun efnahagsmála. En ný bylgja farsóttar á haustmánuðum myndi valda miklu tjóni fyrir atvinnulíf og efnahag landsins.

Nú er lag að fjárfesta í bættum pjóðvegum og endurbótum á peim stöðum sem ferðamenn sækja, svo ekki sé talað um pá heilbrigðispjónustu sem mest hefur mætt á í farsóttinni nú í vor. Ef bóluefni

Nú er lag aơ fjárfesta í bættum pjóðvegum og endurbótum á ferðamannastöðum, svo ekki sé talad um pá heilbrigðispjónustu sem mest hefur mætt á í farsóttinni. Ef bóluefni finnst verठur hægt aô opna landið̃ að̃ fullu en ef ekki purfa læknar að læra meira ádur en óumflýjanleg bylgja farsóttar gengur yfir ad̃ nýju. finnst er hægt að opna landið að fullu en ef ekki, pá vinnst tími fyrir læknastéttina að læra meira um hinn nýja sjúkdóm áður en hin óumflýjanlega bylgja farsóttar gengur yfir að nýju.

Pandemics and the economy

Gylfi Zoëga

Professor of Economics, University of Iceland, PhD in economics

\section{Heimild}

1. Gourinchas PO. „Flattening the pandemic and recession curves, VoxEU. voxeu.org/content/mitigating-covid-economic-crisis-act-fast-and-do-whatever-it-takes - maí 2020 